\title{
EFFECT OF DIETARY BEE HONEY AND BEE POLLEN AS ALTERNATIVE OF ANTIBIOTIC ON GROWTH PERFORMANCE, TIBIA CHARACTERISTICS AND SOME BLOOD PLASMA PARAMETERS OF BROILERS
}

\author{
M.M. Hamed; A.I. El-Faham; F. Abd El-Azeem; N.M. El-Medany, Nematallah G.M. Ali; \\ M.A.M. Abdelaziz and A.Y.M Abdelhady
}

Poultry Production Dept., Fac. of Agric., Ain Shams Univ., Egypt.

\section{SUMMARY}

\begin{abstract}
$\mathrm{A}$ n experiment was conducted to evaluate the effects feeding broiler chicks on corn soybean meal diets supplemented with bee honey $(\mathrm{BH})$, bee pollen $(\mathrm{BP})$ or both as alternative to antibiotics erythromycin (ER) on growth performance, tibia characteristics and some blood plasma parameters. A total of number 150 one - day old chicks of (Cobb) strain were randomly assigned to five dietary treatments $(5$ treatments $\times 3$ replicate groups $\times 10$ chicks in each group). The treatments were: control without supplementation; T1 (ER) 0.0275\%; T2 (BH) 0.10\%; T3, (BP) $0.05 \%$ and T4 (BH, $0.10 \%+\mathrm{BP} 0.05$ ). The main results showed significant effect on body weight, body weight gain and performance index. On contrary there were no significant effect on feed consumption and feed conversion ratio within treatments. The results showed no significant effect on tibia measurements tibia weight (wet and dry), tibia (width and length) and tibia seeder index while there was significant effect on tibia breaking strength, As most of measured parameters there were no significant effect on tibia chemical composition (ASH and $\mathrm{P}$ ) except (Ca) between treatments.
\end{abstract}

Kaywords: bee honey, bee pollen, antibiotics, growth performance.

\section{INTTRDUCTION}

Antibiotic growth promoters (AGPs) have been used for around 60 years in agricultural animal production to enhance growth performance and protect health of animals (Goodarzi et al. 2014). Also, they have been supposed to enhance growth performance of poultry because it changes the intestinal tract, hence and improving absorptive capacity (Visek 1978). However, there are concerns that wider subtherapeutic use of AGPs in animal feed can lead to the development of antibiotic resistance in human pathogens, which is considered as a potential risk for humans if it is transferred from animal to human microbiota (Toghyani et al. 2015). Thus, poultry producers are looking for strategies to allow them to reduce or eliminate the use of AGPs in poultry production. Therefore, there is growing demand for alternatives to the subtherapeutic use of antibiotics which can sustain or improve broiler performance and the safety of poultry products.

Bee honey and bee pollen are substances had produced by honey bee, it can be regarded as a good food, Antimicrobial, antiviral and antiparasitic activity and anti-oxidant, because these functions result to that honey bee products including on many substance such as carbohydrate, protein, amino acid, minerals, vitamins, organic acids, Fatty acids Polyphenols, flavonoids (quercetin, luteolin, kaempferol, apigenin, chrysin, galangin), and phenolic acids (Gheldof and Engeseth 2002, Feas 2012).

Therefore, many researchers tried to find some natural feed additives such as Bee honey and bee pollen to be used in poultry farms to reduce the expected harmful effects, the results of many previous reports demonstrated that bee products has a beneficial influence on body weight gain (BWG), feed consumption (FC), feed conversion ratio (FCR), and productive performance in different poultry species (Osunkeye et al., 2016, Hegazi et al., 2013 and Obun et al., 2008). By contrast, other researchers did not find any positive effects of using dietary bee products on growth performance of broiler chicks (Hosseini et al., 2016 and Monsuru et al,. 2012).

Therefore, feeding trials were conducted to investigate the supplementation of bee products (bee honey $(\mathrm{BH})$, bee pollen (BP), or both as an alternative to AGPs erythromycin (ER) on growth performance, some tibia measurements and composition and some blood parameter. 


\section{Hamed et al.}

\section{MATERIAL AND METHODS}

150 unsexed Cobb broiler chicks one-day-old were randomly distributed into (5 treatments $\mathrm{x}$ three 3 replicates x 10 chicks). Chicks were housed in battery cages and kept under similar environment during 1-35 days of age. Feed and water were supplied ad-libitum. Diets (Table 1) were formulated to be offered during the following periods; starter (1-14 d), grower (15-28 d) and finisher (29-35 d) diets. Bee honey (BH) and bee pollen (BP) were obtained from the Honey bee Research Section, Faculty of Agriculture, Ain Shams University, Egypt. Colistin sulfate (CS) used in this study was obtained from the local market.

The experimental treatments were as follows: The treatments were: control without supplementation; $\mathrm{T}_{1}$ (ER) $0.275 \% ; \mathrm{T}_{2}(\mathrm{BH}) 0.10 \% ; \mathrm{T}_{3},(\mathrm{BP}) 0.05 \%$ and $\mathrm{T}_{4}(\mathrm{BH}, 0.10 \%+\mathrm{BP} 0.05)$.

The diets were formulated to meet the nutrient requirements of the broiler chicks according to cobb broiler guide.

Table (1). Composition and calculated analysis of the starter, grower and finisher experimental basal diets.

\begin{tabular}{lccc}
\hline Ingredient \% & $\begin{array}{c}\text { Starter } \\
\text { (1-14 days })\end{array}$ & $\begin{array}{c}\text { Grower } \\
\text { (15-28 days) }\end{array}$ & $\begin{array}{c}\text { Finisher } \\
(29-35 \text { days })\end{array}$ \\
\hline Yellow Corn & 57.72 & 61.50 & 64.01 \\
Soybean meal $(44 \%)$ & 30.00 & 28.00 & 25.25 \\
Corn Gluten meal (60\%) & 6.30 & 4.00 & 4.00 \\
Soybean Oil & 1.80 & 2.60 & 3.20 \\
Mono calcium phosphate & 1.60 & 1.50 & 1.35 \\
Limestone & 1.45 & 1.35 & 1.25 \\
L-lysine HCL & 0.30 & 0.24 & 0.17 \\
Dl Methionine & 0.23 & 0.21 & 0.17 \\
Salt (Nacl) & 0.30 & 0.30 & 0.30 \\
Vit. \& min. premix* & 0.30 & 0.30 & 0.30 \\
Total & 100.00 & 100.00 & 100.00 \\
Calculated chemical analysis* & & & \\
Crude protein \% & 22.01 & 20.03 & 19.03 \\
ME (Kcal/kg) & 3015 & 3090 & 3172 \\
Calcium \% & 0.91 & 0.85 & 0.78 \\
Available phosphorus \% & 0.45 & 0.43 & 0.39 \\
Lysine \% & 1.33 & 1.19 & 1.06 \\
Methionine\% & 0.61 & 0.55 & 0.50 \\
Methionine + cysteine \% & 0.98 & 0.89 & 0.83 \\
\hline
\end{tabular}

* Each 3 Kg of premix containing: 15000000 I.U.Vit, A, 3000000 I.U Vit. D 50g. Vit E, 3000mg Vit. K3. $3000 \mathrm{mg}$ Vit. B1, $8000 \mathrm{mg}$. Vit B2, $4000 \mathrm{mg}$. Vit B6, 20mg. vit. B12, $15000 \mathrm{mg}$ pantothenic acid, $60000 \mathrm{mg}$. niacin, $1500 \mathrm{mg}$. folic acid, 200mg. biotin, $200000 \mathrm{mg}$ Vit C, $700 \mathrm{gm}$. choline chloride, $80 \mathrm{gm}$. Mn, $80 \mathrm{gm}$. zinc, $60 \mathrm{gm}$. iron, $10 \mathrm{gm}$. CU, $1 \mathrm{gm}$. Iodine, and $0.2 \mathrm{gm}$ selenium, where $\mathrm{CaCo} 3$ was taken as a carrier up to $3 \mathrm{~kg}$, the inclusion rate was $3 \mathrm{Kg}$ premix/ton feed.** Calculated analysis of the experimental diets were done according to (NRC, 1994).

\section{Growth performance}

The performance parameters include live body weight (LBW), body weight gain (BWG), feed consumption (FC), feed conversion ratio (FCR), mortality number and performance index (PI) for each replicate for all treatments were determined.

\section{Slaughter processing}

At $35 \mathrm{~d}$. of age, 4 birds close to average body weight of their respective treatments were selected for slaughtering. 


\section{Tibia characteristics}

After slaughter processing the right tibia bone was collected and cleaned from soft tissues and weighed. The tibias were dried $\left(105^{\circ} \mathrm{C}\right.$ for $\left.24 \mathrm{hrs}\right)$ then weight and length and diameter of each tibia were measured using a digital caliper to the nearest $\mathrm{mm}$. Tibia seedor index were calculated according to Seedor et al. (1991) and tibia breaking strength was determined by using the method prescribed by Flemming et al. (1998). Tibia composition \% (ash, Ca and P) were performed using standard AOAC procedure (AOAC, 1995).

\section{Blood plasma parameters}

Blood samples from randomly taken four chickens of each treatment were immediately collected, during their exsanguination after slaughtering, into heparinized tubes and plasma were separated by centrifugation at $3000 \mathrm{rps}$ for 15 minutes. Plasma constituents including calcium and phosphorus were determined calorimetrically by using spectrophotometer and suitable commercial diagnostic kits.

\section{Statistical analysis}

Data subjected to one-way analysis of variance using SAS (2001). Differences among means were detected by using Duncan's multiple range test (Duncan, 1955). The following model was Used:

Where $\mathrm{Y}_{\mathrm{ij}}=$ Observation for each dependent

$$
Y_{i j}=G+T_{i}+e_{i j}
$$

Variable $\mathrm{G}=$ General mean

$\mathrm{T}_{\mathrm{i}}=$ Treatment effects $(\mathrm{I}=1,2 \ldots$ and 5$)$.

$\mathrm{e}_{\mathrm{ij}}=$ Random error.

\section{RESULTS AND DISCUSSION}

\section{Productive performance}

The impact of bee honey and bee pollen supplementation on LBW, BWG, FC, FCR, PI and mortality rate of Cobb broiler chicks are presented in Table (2). The averages of initial weight of broiler chicks at one-day of age were insignificantly different among all treatments. Finial LBW recorded significant difference among treatments for chicks in the $\mathrm{T}_{1-4}$ that were significantly increased $(\mathrm{P}<0.05)$ when compared to chicks of control groups (1569.08 g). The best LBW showed in $\mathrm{T}_{2}$ and $\mathrm{T}_{4}(1740.42$ and $1779.06 \mathrm{~g})$. Also, BWG showed similar trend, the best BWG showed in $\mathrm{T}_{2}$ and $\mathrm{T}_{4}(1703.32$ and $1742.34 \mathrm{~g})$. These results agreed with (Obun et al., 2008; Hegazi et al., 2013; Osunkeye et al., 2016; Oyegunle et al., 2016; Sakine et al., 2016; Abuoghaba and Ismail 2018 and klaric et al., 2018) they indicated that addition of BH or BP in broiler diets led to significant increases in LBW and BWG. But disagreed with (Monsuru et al., 2012) who didn't found significant effects on LBW or BWG by bee honey addition in broiler diets.

Data in Table (2) Recorded that FC per chicks was decreased by feeding BH, BP or both $\left(\mathrm{T}_{2-3}\right)$ comparable to birds whose diet contained ER $\left(\mathrm{T}_{1}\right)$ or control diets. The corresponding figures were 2762.53, 2768.40 and $2799.73 \mathrm{~g}$ for $\left(\mathrm{T}_{2-4}\right)$ vs $2826.00\left(\mathrm{~T}_{1}\right) 2811.00 \mathrm{~g}$ for control group, respectively without any significant differences. The figures of feed conversion ratio (FCR) indicated no significant effect among treatments, but better FCR value were detected for the chicks of diets supplemented with $\mathrm{BH}\left(\mathrm{T}_{2}, 1.62\right)$ or $\mathrm{BH}+\mathrm{BP}\left(\mathrm{T}_{4}, 1.61\right)$, respectively. On the other hand, the worse FCR were found in chicks fed control (1.83) diets. The results showed significant effect in PI between treatments, the best result recorded in $\left(T_{2}, 107\right)$ and (T4, 109) compare to another treatments. These results agreed with (Monsuru et al., 2012 and Hosseini et al., 2016) who reported that the BH or BP supplementation had no significant effect on FC and FCR of broiler chicks compared with that of the control group, while disagreed with (Farag and El-Rayes, 2016 and Obun et al., 2008) who reported that supplementation of bee honey or bee pollen had significant effect in FC and FCR in broiler chicks.

This improvement in broiler performance might be due to BH and BP contents; carbohydrates, vitamins (A, $B_{1}, B_{2}, B_{3}$ and biotin), enzymes, flavonoids, fatty acids and minerals, which are all important in growth performance enhancement and also, these findings can be attributed antimicrobial potential of the components of the $\mathrm{BH}$ and $\mathrm{BP}$, resulting in better intestinal health and improving digestion and absorption (Matzke, 2003; Feas, 2012 and Bogdanov Pascoal et al., 2014). 
Table (2): Effect of dietary treatments on productive performance of broiler chicks.

\begin{tabular}{lccccccc}
\hline Item & \multicolumn{3}{c}{ Treatment } & \multirow{2}{*}{ SEM. } & Sign. \\
\cline { 2 - 5 } & Control & $\mathrm{T} 1$ & $\mathrm{~T} 2$ & $\mathrm{~T} 3$ & $\mathrm{~T} 4$ & & \\
\hline Initial weight & 36.03 & 37.00 & 37.10 & 35.30 & 36.60 & 0.31 & N. S \\
Live body weight $(\mathrm{g})$ & $1569.08^{\mathrm{c}}$ & $1709.11^{\mathrm{ab}}$ & $1740.42^{\mathrm{a}}$ & $1669.00^{\mathrm{b}}$ & $1779.06^{\mathrm{a}}$ & 22.30 & $*$ \\
Body weight gain $(\mathrm{g})$ & $1533.04^{\mathrm{c}}$ & $1672.11^{\mathrm{ab}}$ & $1703.32^{\mathrm{ab}}$ & $1633.31^{\mathrm{b}}$ & $1742.34^{\mathrm{a}}$ & 22.69 & $*$ \\
Feed consumption $(\mathrm{g})$ & 2811.00 & 2826.00 & 2762.53 & 2768.40 & 2799.73 & 35.61 & N. S \\
Feed conversion ratio & $1.83^{\mathrm{a}}$ & $1.67^{\mathrm{b}}$ & $1.62^{\mathrm{b}}$ & $1.69^{\mathrm{b}}$ & $1.61^{\mathrm{b}}$ & 0.03 & N. S \\
Performance index & $86.21^{\mathrm{b}}$ & $101.37^{\mathrm{a}}$ & $107.35^{\mathrm{a}}$ & $98.62^{\mathrm{ab}}$ & $110.86^{\mathrm{a}}$ & 10.87 & $*$ \\
Mortality rate & $1 / 30$ & $2 / 30$ & $0 / 30$ & $0 / 30$ & $0 / 30$ & & \\
\hline
\end{tabular}

$a, b$ and $c$ means in the same raw with different superscripts in the same raw are significantly $(p \leq 0.05)$ different. N.S.: non-significant. Control: No additives, T1: ER (Erythromycin) 0.0275\%, T2: BH (Bee honey) 0.10\%, T3: BP (Bee pollen) $0.05 \%$ and T4: $(B H+B P) 0.10 \%+0.05 . P I=$ Live body weight $(\mathrm{kg}$ )Feed conversion ratio $* 100$ (North, 1981).

Under the conditions of the present study all chicks appeared healthy and total mortality rate was $2.0 \%$ ( 3 chicks) during the total experimental period (35 days) and it seems that inclusion of different levels of bee honey and bee pollen or both $\left(\mathrm{T}_{2-4}\right)$ had positively influenced health conditions and mortality rate (Table). This result agreed with Obun et al. (2008); Hegazi et al. (2013) and Oyegunle et al. (2016) they reported that dietary supplementation of $\mathrm{BH}$ could reduce the mortality rate, this might be account for improving the immune response (Gheldof, 2002 and Hegazi et al., 2013). In addition, BH stimulates the activity of leukocytes, stimulates lymphocytes proliferation and activates phagocytes, the honey stimulates monocytes to release cytokines, which are activators of immune response to infection. (Abuharfeil et al., 1999).

The impact of bee honey and bee pollen supplementation on some tibia trait; measurements and chemical composition of broiler chicks are presented in Table (3) The achieved findings indicated that tibia weight (wet and dry) g, tibia (width, length and seedor index) for chicks treated with different dietary treatments were improved in birds of $\mathrm{T}_{2-4}$ compare to those of ER and control groups. However, there were not any significant differences among treatments. While, significant differences in tibia breaking strength were detected among treatments, in which chicks fed diets supplemented with $\mathrm{BH}+\mathrm{BP}\left(\mathrm{T}_{4}, 28.25 \mathrm{~cm} / \mathrm{kg}\right)$ were the highest compared with the other treatments.

The figures of tibia chemical composition indicated significant differences among treatments in $\mathrm{Ca} \%$, the best results showed in $\mathrm{BH}$ with or without $\mathrm{BP}\left(\mathrm{T}_{2}\right.$ and $\left.\mathrm{T}_{4}\right)$. On another hand, there were non-significant effect on $\mathrm{ASH} \%$ and $\mathrm{P} \%$ among treatments while, there were numerical improvements in $\mathrm{T}_{2-4}$ groups compared to ER and control groups.

This result agreed with Mansurea et al. (2012), Oyegunle et al. (2016) and Rabie et al. (2018) they showed that addition of $\mathrm{BH}$ or BP in broiler diets improved the percentage of tibia weight and increased the percentage of calcium and phosphorus. These results might be due to improving calcium and phosphorus metabolism, as a result of the vitamin D content in $\mathrm{BH}$ and $\mathrm{BP}$.

Results in Table (4) recorded that after 35 days of treatments, no changes in plasma calcium or phosphorus among treatments. However, numerically plasma $\mathrm{Ca}$ and $\mathrm{P}$ were insignificantly lower, when the chicks were treated with $\mathrm{ER}, \mathrm{BH}, \mathrm{BP}$ or $\mathrm{BH}+\mathrm{BP}\left(\mathrm{T}_{2-4}\right)$ compared to control treatment. The decrease level of plasma calcium and phosphorus gave indicator on improving calcium and phosphorus metabolism. This result agreed with Isaac and and Rosemary (2015) who found that addition of BH $10 \mathrm{ml}$ or $20 \mathrm{ml} /$ liter water in laying hens had effect on the level of plasma calcium, but found no effect on the level of plasma phosphorus.

\section{CONCLUSION}

It is recommended to use bee honey $(0.10 \%)$ with or without bee pollen $(0.05 \%)$ as a growth promoter in broiler to improve the growth performance, tibia measurements and composition, as an alternative to antibiotics. 
Table (3). Effect of dietary treatments on some of tibia measurements and composition of broiler chicks.

\begin{tabular}{|c|c|c|c|c|c|c|c|}
\hline \multirow{2}{*}{ Item } & \multicolumn{5}{|c|}{ Treatment } & \multirow{2}{*}{ Sem. } & \multirow{2}{*}{ Sign. } \\
\hline & Control & T1 & $\mathrm{T} 2$ & T3 & $\mathrm{T} 4$ & & \\
\hline \multicolumn{8}{|l|}{ Some of tibia measurements } \\
\hline Wet tibia weight $(\mathrm{g})$ & 6.17 & 6.06 & 7.17 & 7.74 & 6.06 & 0.25 & N. S \\
\hline Dry tibia weight (g) & 3.31 & 3.00 & 3.87 & 3.48 & 3.43 & 0.12 & N. S \\
\hline Tibia length (mm) & 79.31 & 77.30 & 81.09 & 80.52 & 81.67 & 0.59 & N. S \\
\hline Tibia width (mm) & 7.44 & 7.36 & 7.64 & 7.22 & 7.92 & 0.13 & N. S \\
\hline Tibia seeder index & 0.41 & 0.39 & 0.47 & 0.47 & 0.41 & 0.06 & N. S \\
\hline Tibia breaking strength & $19.98^{\mathrm{b}}$ & $20.26^{\mathrm{b}}$ & $23.51^{\mathrm{ab}}$ & $22.23^{\mathrm{ab}}$ & $28.25^{\mathrm{a}}$ & 5.05 & $*$ \\
\hline \multicolumn{8}{|l|}{ Tibia composition $\%$} \\
\hline Ash & 42.35 & 45.18 & 46.43 & 45.60 & 44.70 & 0.84 & N. S \\
\hline Calcium & 16.37 & $14.02^{\mathrm{b}}$ & $17.27^{\mathrm{a}}$ & $16.94^{\mathrm{ab}}$ & $17.44^{\mathrm{a}}$ & 0.41 & $*$ \\
\hline Phosphorus & 7.49 & 8.27 & $8.52^{\mathrm{a}}$ & 8.10 & 7.88 & 0.01 & N. S \\
\hline
\end{tabular}

Table (4): Effect of dietary treatments on some of plasma calcium and phosphorus of broiler chicks.

\begin{tabular}{|c|c|c|c|c|c|c|c|}
\hline \multirow{2}{*}{ Item } & \multicolumn{5}{|c|}{ Treatments } & \multirow{2}{*}{ Sem. } & \multirow{2}{*}{ Sign. } \\
\hline & Control & $\mathrm{T} 1$ & $\mathrm{~T} 2$ & T3 & T4 & & \\
\hline Calcium (mg/dl) & 9.87 & 9.46 & 9.35 & 9.50 & 8.33 & 0.30 & N.S \\
\hline Phosphorus (mg/dl) & 4.65 & 4.27 & 4.89 & 3.83 & 3.87 & 0.09 & N. S \\
\hline
\end{tabular}

\section{REFERENCE}

Abuharfeil, N., R. Al-Oran, and M. Abo-Shehawa, (1999). The effect of BH on the proliferate activity of human B-and T-lymphocytes and activity of phagocytes. Food Agric. Immunol., 11:169-77.

Abuoghaba, A. A., and I. I. Ismail, (2018). Impact of bee pollen supplementation on productive performance, some hematological parameters, blood constituents and semen physical characteristics of sinai chickens,. Egypt. Poult. Sci. (38) (II): (621:635).

AOAC (1995). Official methods of analysis. 16th ed. Association of Officials Analytical Chemists, Arlington, TX, USA.

Bogdanov, S. and Matzke A: Honig - eine natürliche Süsse. In Matzke A, Bogdanov (ed). (2003). "Der Schweizerische Bienenvater, Bienenprodukte und Apitherapie." Winikon: Fachschriftenverlag VDRB, pp 7-40.

Duncan D.B. (1955). Multiple range test and multiple F-tests. Biometrics; 11:1-42.

Feás, X., M.P. Vázquez-Tato, L. Estevinho, J.A. Seijas and A. Iglesias (2012). Organic Bee Pollen: Botanical Origin, Nutritional Value, Bioactive Compounds, Antioxidant Activity and Microbiological Quality. Molecules ; 17:8359-77.

Flemming, R.H., L. Mctier, and C.C. Whitehead. (1998). Medullary bone and humeral breaking strength in laying hens. Research in Veterinary Science, 64: 63-67.

Gheldof N. and N.J. Engeseth (2002). Antioxidant capacity of honeys from various floral sources based on the determination of oxygen radical absorbance capacity and inhibition of in vitro lipoprotein oxidation in human serum samples. J Agric Food 35 Chem 50:3050-3055.

Goodarzi B., A. F., Mader, F. Knorr, I. Ruhnke, I. Röhe, A. Hafeez, K. Männer, and J. Zentek, (2014 )., The effects of different thermal treatments and organic acid levels on nutrient digestibility in broilers., Poultry Science $93: 1159-1171$. 


\section{Hamed et al.}

Hegazi, A., A.M. Abdou, and F.A. Allah. (2013). Egyptian propolis 9-its effect on chicken productivity and immune response against Newcastle disease vaccine. British Journal of Poultry Sciences I, 25-30.

Hosseini S.M., M. Vakili Azghandi, S. Ahani and R.N .ourmohammad (2016). Effect of bee pollen and propolis (bee glue) on growth performance and biomarkers of heat stress in broiler chickens reared under high ambient temperature., Journal of Animal and Feed Sciences, 25, 45-51.

Isaac Osakwe and Rosemary Igw, (2015), , physiological responses of laying birds fed honey and vitamin c in drinking water, tropentag, berlin, germany conference on international research on food security, natural resource management and rural development.

Klaric I., L. Miskulin, V. Seric, A. Vumic, J. Jonjic, M. Miskulin. (2018)., The effects of propolis and bee pollen supplementation on biochemical blood parameters of broilers., acta veterinaria-beograd., 68 (2), 190-200.

Monsuru O.A., B.O. Kabir, E.A. Titilayo, E.O. Kayode, O.A. Oluwatosin, A.A. John, J.W. Tolulope, O.O. Emmanuel, and A.O.M. Olusegun. (2012). Growth, Mineral Deposition, and Physiological Responses of Broiler Chickens Offered Honey in Drinking Water during Hot-Dry Season., International Journal of Zoology Volume 2012, Article ID 403502, 6 pages.

North, O. M. (1981). Commercial production Mannual. 2nd ED., AVI publishing company, Inc. Westpor, Connecticut.

NRC (1994). National Research Council. Composition of poultry feedstuffs. National Academy of Sciences. Washington, D.C. USA.

Obun, C.O., M.S. Yahaya, O.A. Olafadehan, A.S. Kehinde, D.S. Allison, A.M. Yusuf,and U. Farouk (2008). Dietary value of honey and it effects on abdominal fat deposit, blood and serum profile of finisher broiler chicks., journal of agriculture, forestry and the social sciences (joafss), vol.6, no. 2,173:181.

Osunkeye O.J., P.O. Fakolade, B.O. Alabi, V.O. Akinduro, B.E. Olorede., (2016). Physiological, Serum and Haematological Responses of Broiler Fed Honey at Varying Levels of Inclusion in the Diet.,Journal of Natural Sciences Research., Vol.6, No.9,ISSN 2224-3186 (Paper) ISSN 2225-0921 (Online).

Oyegunle E.O., O. Faith, Sorungbe, O.A. Monsuru, O. Oluwadamilola, O.O. Anuoluwapo, (2016 ). Effect of different levels of honey on physiological, growth and carcass traits of broiler chickens during dry season., Acta argiculturae Slovenica, 108/1, 45-53.

Pascoal A, S. Rodrigues, A. Teixeira, X. Feás, L.M. Estevinho (2014). Biological activities of commercial bee pollens: Antimicrobial, antimutagenic, antioxidant and antiinflammatory. Food and Chemical Toxicology; 63:233-9.

Rabie A.H., A.M. El-Kaiaty, M.S.H. Hassan and F.K.R. Stino (2018)., Influence of Some Honey Bee Products on Some Haematological And Immunological Parameters And Meat Quality In Broilers., Egypt. Poult. Sci. Vol (38)(II): (533-549).

Sakine B., R. Shaeban, A.K.T., Mohammad, T. Golamhosein, and N.K.M. Seyed. (2016). Effects of propolis, royal jelly, honey and bee pollen on growth performance and immune system of Japanese quails., Veterinary Research Forum. ; 7 (1) 13 - 20.

SAS (2001). Statistical Analysis System, SAS User's Guide: Statistics, Inc., Cary, NC. USA.

Seedor J.G., H.A. Quarruccio and D.D. Thomposon (1991). The bisphosphonate alendronate (MK-2017) inhibits bone loss due to ovariectomy in rats. Journal of bone and minral reserch, 6:339-346.

Soha A. Farag and T.K. El-Rayes, (2016). Effect of Bee-pollen Supplementation on Performance, Carcass Traits and Blood Parameters of Broiler Chickens. AsianJournal of Animal and Veterinary Advances, 11: 168-177.

Toghyani, M. S.k Mosavi, M. Modaresi and N. Landy (2015)., Evaluation of Kefir as a Potential Probiotic on Growth Performance, Serum Biochemistry and Immune Responses in Broiler Chicks Animal Nutri, 1, pp. 305-309.

Visek, W.J. (1978). The mode of growth promotion by antibiotics. J. Anim. Sci., 46: 1447-1469. 
تاثير إضافة عسل النحل وحبوب اللقاح كبديل للمضادات الحيوية على الأداء الإتتاجي وصفات العظم وبعض مكونات بلازما الام لبدارى التسمين

\author{
محم مصطفى حامد ,أحمد إبراهيم سليمان الفحام , فتحي عبدالعظيم ,نبيل محم حسن المدني ,نعمة الله جمال الدين ححم على \\ مروان عبدالعزيز محمود عبدالعزيز ,عبدالرحمن يوسف محمد, \\ قسم إنتاج الدواجن - كلية النزراعة - جامعة عين شمس - مصر
}

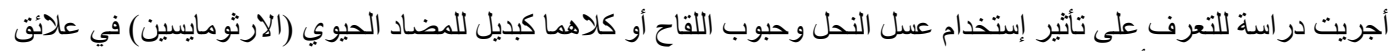

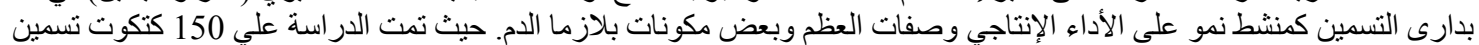

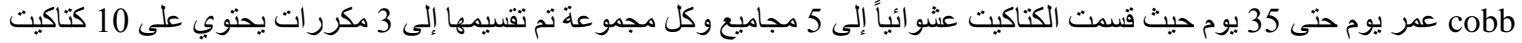

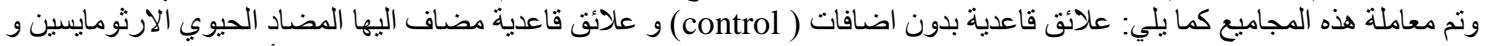
عسل النحل و حبوب اللقاح او كلاهما بمعدل \%(0.0275 -0.10 - 0.05 - (0.10+0.05) بالترتيب. وسجلت أهم النتائج كالتالي 1- وجود زيادة معنوية في وزن الجسم و الجسم المكتسب و كانت افضل النتائج في الطيور المغذاه علي عسل النحل و عسل النحل مع النع حبوب اللقاح 2- لم تنتاثبر استهاحلاك العلف في المعاملات المختلفة و لكن تحسن معامل التحويل الغذائي رقميا في الطيور المغذاه علي حبوب اللقاح و العسل او كلانهما

3- تحسين معنوي في معادلات الاداء الانتاجي (PI) في الطيور المغذاه علي علائق مضاف اليها عسل النحل و حبوب اللقاح او كلاها

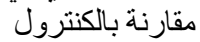

4- استخدام عسل النحل و حبوب اللقاح في علائق دجاج التسمين ادي الي تحسين صفات العظم و خصوصا قوة الكسر و حسنت بشكل

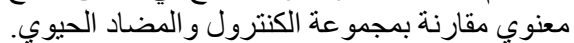
5- استخدام عسل النحل و حبوب اللقاح ادي الي تحسين التركيب الكميائي لعظمة الساق و خصوصا نسبة الكالسيوم. توصي هذه الدر اسة بأنه يمكن استخدام عسل النحل بمفرده او مضاف اليها حبوب اللقاح كمنشط نمو بديل للمضاد الحيوي الارثرومايسين

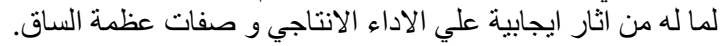

